\title{
Dexbrompheniramine Maleate
}

National Cancer Institute

\section{Source}

National Cancer Institute. Dexbrompheniramine Maleate. NCI Thesaurus. Code C61706.

The maleate salt form of dexbrompheniramine, an alkylamine derivative with

anticholinergic and sedative properties. Dexbrompheniramine is a histamine $\mathrm{H} 1$-receptor antagonist that competes with histamine for the $\mathrm{H} 1$-receptor sites on effector cells in the gastrointestinal tract, blood vessels and respiratory tract. The antagonistic action of this agent blocks the activities of endogenous histamine, which subsequently leads to temporary relief from the negative histamine-mediated symptoms of allergic reaction such as bronchoconstriction, vasodilation, increased capillary permeability and spasmodic contractions of gastrointestinal smooth muscle. 